\title{
The role of headache management in minor head injury before performing brain CT scan - can intravenous morphine sulfate predict intracranial injury?
}

\author{
Koorosh Ahmadi, M.D., ${ }^{1}$ Amir Masoud Hashemian, M.D., ${ }^{2}$ Elham Pishbin, M.D., ${ }^{2}$ \\ Ali Taheriniya, M.D., ${ }^{1}$ Saba Jafarpour, M.D., ${ }^{3}$ Vafa Rahimi-Movaghar, M.D. ${ }^{4}$
}

\begin{abstract}
1Department of Emergency, Alborz University of Medical Sciences, Karaj, Iran; ${ }^{2}$ Department of Emergency, Mashad University of Medical Sciences, Mashad, Iran;

${ }^{3}$ Sina Trauma and Surgery Research Center, Tehran University of Medical Sciences, Tehran, Iran;

${ }^{4}$ Sina Trauma and Surgery Research Center, Tehran University of Medical Sciences, Tehran, Iran; Department of Neurosurgery, Shariati Hospital, Tehran University of Medical Sciences, Tehran, Iran; Research Centre for Neural Repair, University of Tehran, Tehran, Iran
\end{abstract}

\begin{abstract}
BACKGROUND: The aim of this study was to examine the association between the responses of headache to IV morphine and the findings of brain $\mathrm{CT}$ scan in minor head injury $(\mathrm{MHI})$, and to propose a new risk indicator to identify patients requiring $\mathrm{CT}$ scanning.

METHODS: A total of $1857 \mathrm{MHI}$ patients $\geq 15$ years of age, presenting with headache and a GCS score of 14 or 15 were included in the study. Intravenous morphine sulfate was administered, and thereafter, patients were assessed for the relief or persistence of headache. Subsequently, a brain CT scan was obtained from all patients.

RESULTS: Patients were divided into two age groups: 15-60 and >60 years. There was a significant association between the response of headache to morphine and the result of brain CT in both age groups $(\mathrm{p}<0.00 \mathrm{I})$. In patients aged between I5 and 60 , none whose headache had responded to morphine showed any abnormal findings in CT scan (sensitivity=100\%). In the $>60$ group, sensitivity was $58.3 \%$ for abnormal CT and $71.4 \%$ for neurosurgical intervention.
\end{abstract}

CONCLUSION: This study suggests that a headache not relieved by morphine is a risk indicator for intracranial injury. This protocol can be used in rural areas with limited access to $\mathrm{CT}$ scan as an adjunct to the existing criteria for selecting patients with MHI for $\mathrm{CT}$ scanning.

Key words: Brain injuries; computed tomography; craniocerebral trauma; headache; morphine; pain management.

\section{INTRODUCTION}

More than I.5 million people sustain traumatic brain injury in the United States annually. ${ }^{[1]}$ Minor head injuries (MHI) account for a majority of cases in head trauma. ${ }^{[2]}$ The term "minor head injury" is used with variable definitions. It is

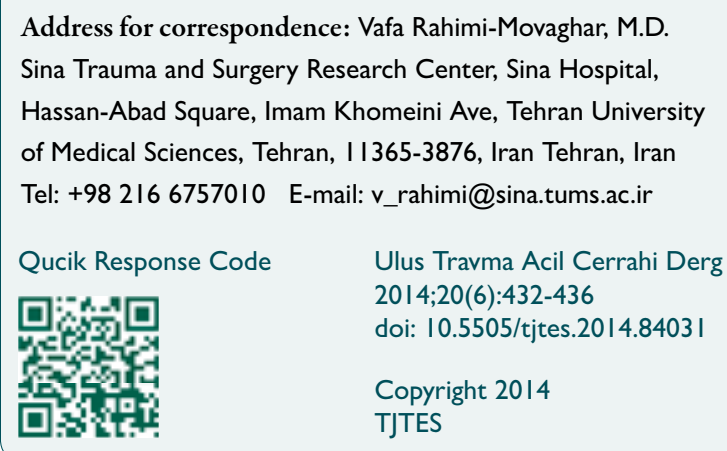

typically defined as history of blunt head trauma in a patient presenting with Glasgow Coma Scale (GCS) score of 13-15. Some authors include post-traumatic disorientation, loss of consciousness and/or amnesia for the traumatic event in the definition, classifying patients without mentioned alteration in mental status into another category: minimal head injury. [3] Some others exclude patients with the GCS score of 13 from the mild category due to higher incidence of intracranial lesions requiring surgical operations. ${ }^{[4]}$

The decision of which patients with $\mathrm{MHI}$ should undergo computed tomography (CT) evaluation has long been a subject of controversy. ${ }^{[5]}$ On the one hand, incidence of intracranial lesions, especially those clinically significant and more specifically those requiring operative intervention is relatively low in $\mathrm{MHI}$ (less than $10 \%$ and less than $1 \%$, respectively). [6] Thus, failure to detect clinically insignificant intracranial 
lesions seems to be an acceptable risk of selecting patients for CT scanning. ${ }^{[3]}$ For instance, it has been shown that the presence of isolated contusion in CT images of patients with $\mathrm{MHI}$ without any other space occupying lesions does not worsen the short term prognosis and does not increase the need for neurosurgical operations. ${ }^{[7]}$ Moreover, precluding unnecessary $\mathrm{CT}$ scanning can significantly reduce health care expenditure ${ }^{[6]}$ and resource use, as well as minimizing radiation exposure, ${ }^{[8]}$ saving time, and preventing unnecessary transfer from centers that CT scan is not available. ${ }^{[9]}$ On the other hand, there is an opposing opinion promoting a more liberal use of CT scan considering the unfavorable outcomes of missing an abnormality. The former is more dominant in a context that health policies emphasize on cost-effective use of resources or where resources are scarce and CT is not extensively available, whereas the latter is favored in a context that the fear of litigation is high. ${ }^{[5]}$ Several studies have assessed different indicators predicting abnormal CT scan, ${ }^{[10-18]}$ and different criteria and guidelines have been developed for judicious utilization of CT scan aiming to reduce the number of unnecessary scans and at the same time not to jeopardize optimal patient care. ${ }^{[3,4,6,9,19-21]}$ The Canadian CT Head Rule $(\mathrm{CCHR})^{[3]}$ and the New Orleans Criteria (NOC) ${ }^{[6]}$ are among the most widely studied decision rules. ${ }^{[8,22-27]}$

Headache is a very prevalent symptom in the victims of $\mathrm{MHI}$. [28,29] There is no consensus if headache is a reliable indicator of intracranial injury in these patients. ${ }^{[10]} \mathrm{It}$ is considered a risk indicator in the criteria developed by Miller et al. ${ }^{[19]}$ and Haydel et al. (NOC); ${ }^{[6]}$ however, not in the $\mathrm{CCHR}^{[3]} \mathrm{A}$ clinical policy established by a multidisciplinary panel recommends considering brain $\mathrm{CT}$ scan in $\mathrm{MHI}$ patients with a GCS score of 15 and no history of loss of consciousness/ amnesia if they have severe headache. ${ }^{[4]}$ However, according to a systematic review and meta-analysis carried out by Pandor et al., headache is not a reliable predictor of intracranial injury in adults. ${ }^{[1]}$ Headache is a major contributor to post concussive syndrome and long term disability after mild traumatic brain injury, and early utilization of analgesics might affect the long term outcome. However, the pain is usually undertreated in emergency departments. Paracetamol and non-steroidal anti-inflammatory drugs (NSAIDs) are among the most widely used analgesics in mild traumatic brain injury, followed by opiates. ${ }^{[30]}$ The effect of morphine in the management of pain in trauma patients, particularly limb trauma is well-established. ${ }^{[31]}$ The association between the response of headache to IV morphine and the results of brain $\mathrm{CT}$ scan in $\mathrm{MHI}$ was aimed to be examined, speculating that a headache not relieved by morphine is more likely to be associated with a structural damage that can be observed in the CT scan. The ultimate goal of this study was to propose a new protocol in the selection of patients for CT scanning, particularly to reduce the costly and time-consuming process of patient transfer in rural areas of developing countries, where CT scan and neurosurgery experts are not easily accessible.

\section{MATERIALS AND METHODS}

This prospective study was conducted between April 2010 and July 2013 in three major teaching hospitals, each with more than 70.000 annual visits to the emergency department (ED). Patients aged 15 years or older who had sustained blunt head trauma and presented to the ED with headache and a GCS score of I 4 or 15 were considered eligible. Patients with any of the following criteria were excluded: focal neurological deficit, suspected open or depressed skull fracture, signs of basilar skull fracture, post-traumatic seizure, coagulopathy or anticoagulant therapy, vomiting, drug or alcohol intoxication, opium addiction, hypersensitivity to opiate analgesics, any concomitant injury, and refusal to participation in the study. The study was approved by the Medical Ethics Committee of the corresponding universities. Informed consent was obtained from all participants.

Patients were assessed by the attending physicians or supervised residents of emergency medicine. Headache was defined as any head pain, no matter diffuse or local. An initial dose of $0.05 \mathrm{mg} / \mathrm{kg}$ morphine sulfate was administered intravenously to all patients. After 15 minutes, the patients were assessed for presence or absence of headache (respectively equivalent to score $\geq I$ and 0 on 10 -point visual analogue scale [VAS]). Had the headache persisted, another dose of intravenous morphine sulfate $(0.05 \mathrm{mg} / \mathrm{kg})$ was administered. Those patients still having headache 15 minutes after receiving the second dose of morphine were regarded as response-negative, and all others whose pain was relieved (score 0 on VAS) either by one or two dose(s) of morphine were considered response-positive. Since the evaluation process was completed before obtaining brain $\mathrm{CT}$, the patients and the examiners were blind to the results of scanning.

Non-enhanced brain CT imaging was performed and the results were interpreted by staff radiologists blind to the results of clinical assessments. A brain CT scan was considered positive (abnormal) if any of the following lesions were present: Skull fracture, brain contusion, epidural hematoma (EDH), subdural hematoma (SDH), intra-cerebral hemorrhage (ICH),

Table I. The frequency of pathologic findings in brain CT of patients in different age groups

\begin{tabular}{lcc}
\hline Lesion & $15-60$ years & $>60$ years \\
\hline Contusion & 44 & 30 \\
Epidural hematoma & 39 & 16 \\
Subdural hematoma & 27 & 19 \\
Skull fracture & 19 & 12 \\
Intra-cerebral hemorrhage & 18 & 6 \\
Subarachnoid hemorrhage & 9 & 2 \\
Intra-ventricular hemorrhage & 1 & 2 \\
\hline
\end{tabular}


Table 2. Primary and secondary outcomes according to the response of headache to IV morphine in patients aged $15-60$ and $>60$ years

\begin{tabular}{|c|c|c|c|c|c|c|}
\hline & \multicolumn{3}{|c|}{$15-60(n=1667)$} & \multicolumn{3}{|c|}{$>60(n=190)$} \\
\hline & Response + & Response - & Total & Response + & Response - & Total \\
\hline $\mathrm{CT}+$ & $0\left(0^{*}\right)$ & I 44 (4) & I44 (4) & $20(2)$ & $28(5)$ & $48(7)$ \\
\hline CT - & 1363 & 160 & 1523 & 104 & 38 & 142 \\
\hline Total & 1363 & 304 & 1667 (4) & 124 & 66 & $190(7)$ \\
\hline
\end{tabular}

subarachnoid hemorrhage (SAH), or intra-ventricular hemorrhage (IVH). Primary outcome was positive brain CT scan and secondary outcome was neurosurgical intervention.

Patients were divided into two age groups: 15-60 and $>60$ years. For each age group, outcomes were compared in response-positive and response-negative patients using crosstabulation and Chi-square analysis. P-values $\leq 0.05$ were considered statistically significant. Statistical analysis was performed using the SPSS software version 20 (SPSS, Inc., Chicago, IL).

\section{RESULTS}

A total of one thousand eight hundred and fifty-seven patients were included in the study. Three hundred and nightyseven $(21.4 \%)$ were female. Mean age of the participants was 35.5 years; 1667 (89.8\%) aged I5-60 years and 190 (10.2\%) were older than 60 . The majority of patients (78.1\%) had a GCS score of 15 (78.7\% in the $15-60$ and $73.2 \%$ in the over 60 years). Three hundred and twenty patients (17.2\%) had a history of loss of consciousness or amnesia for the traumatic event $(16.6 \%$ of $15-60$ and $23.2 \%$ of $>60)$. Of all patients, one hundred and ninety-two (10.3\%; $8.64 \%$ of $15-60$ and $25.3 \%$ of $>60$ ) had at least one lesion in CT. Brain contusion was the most prevalent pathologic finding in both age groups (Table I). Eleven patients required neurosurgical intervention $(0.6 \%$ overall; $0.240 \%$ of $15-60$ and $3.68 \%$ of $>60$ ).

Table 3. CT findings of patients aged $>60$ years with a headache that was ameliorated by morphine

\begin{tabular}{lc}
\hline Pathology $^{*}$ & Frequency \\
\hline Intra-cerebral hemorrhage & - \\
Contusion & 9 \\
Skull fracture & 3 \\
Subarachnoid hemorrhage & - \\
Subdural hematoma & 8 \\
Epidural hematoma & 3 \\
Intra-ventricular hemorrhage & - \\
\hline *: Three patients had more than one lesion in the CT scan; one had skull fracture \\
+ epidural hematoma and two had skull fractures + brain contusions.
\end{tabular}

Of the one thousand six hundred sixty-seven patients aged between 15 and 60 , the headache was relieved in $81.8 \%$ of the patients after administering intravenous morphine sulfate. Interestingly, none of these 1363 patients had any pathologic findings in the CT scan (Table 2). On the contrary, of the remaining three hundred and four patients in this age group whose headache was not responsive to morphine, $47.4 \%$ had abnormality in the CT scan and 4 required neurosurgical procedures. In $>60$ years age group, one hundred and twenty-four patients $(65.3 \%)$ reported their headache to be ameliorated by morphine. However, twenty of them had pathologies in the CT scan (Table 3). Two patients in this category had subdural hematomas necessitating neurosurgical interventions.

Statistical analysis revealed a significant association between the response of headache to IV morphine and the results of brain CT in both age groups (Pearson Chi-Square $=706.676$ for 15-60 and 15.774 for >60; p-values <0.00I). In other words, the rate of abnormal brain $\mathrm{CT}$ scan was significantly lower in patients whose headache was ameliorated by morphine. This protocol showed a sensitivity of $100 \%$, specificity of $89.5 \%$ and accuracy of $90.4 \%$ for detecting abnormal CT scan in the age group of 15-60 years. In the age group of $>60$, though, sensitivity was $58.3 \%$ for the primary outcome and $71.4 \%$ for the secondary outcome.

\section{DISCUSSION}

The purpose of this study was to propose a new protocol in identification of cases that should undergo CT scanning in minor head injury of the adult population. Patients with minor head injuries, presenting with a GCS score of 14 or 15 , and with a complaint of headache were assessed for the relief of the headache by morphine, and patients whose headache was relieved by morphine were compared to those who did not respond to morphine with respect to abnormal CT rate and rate of operative interventions. To the best of our knowledge, no previous study has assessed the association of pain relief by analgesics and pathologic findings in imaging studies. The results of this study put forward that in patients aged 15-60 years, the response of headache to morphine has a sensitivity of $100 \%$ for any abnormal findings in the brain CT scan. Therefore, we propose for this age group that a headache not relieved by morphine is an indicator for the need to 
perform brain CT scan. This protocol can help physicians in rural areas with limited access to CT scan and neurosurgical services to decide on selecting patients to be transferred to an equipped center.

Morphine is one of the most widely used analgesics for trauma patients in the emergency departments. ${ }^{[3]}$ However, patients with head trauma are less likely to receive opiate analgesics in the emergency departments due to the concern of masking the symptoms of traumatic brain injury and making the re-evaluation of patients difficult. ${ }^{[32]}$ In addition, morphine has other unfavorable side effects such as respiratory depression, increase in intracranial pressure, hypotension, ${ }^{[33]}$ and decrease in cerebral perfusion pressure. ${ }^{[34]}$ Nevertheless, none of these effects were observed in our study. It seems that the concern is more prominent in critically ill and/or severely injured patients and in higher doses of morphine. Furthermore, effects of opiates can be reversed by administering opioid antagonists (e.g. naloxone). Thus, we feel that its benefit in pain management and presumed reduction of unnecessary referrals for CT scanning outweighs the risk.

Our suggested protocol has relatively low sensitivity for detecting abnormal CT scan (58.3\%) and need for surgical intervention $(71.4 \%)$ in patients over 60 years of age. There is evidence that due to age-related changes, threshold of injury is lower in elderly people and the guidelines used in the general population cannot be applied to this group. ${ }^{[18]}$ As a result, brain CT scan is recommended for all elderly patients (>60 or $>65^{[3]}$ years of age) sustaining minor head injury.

Current study has some limitations. Most importantly, due to a deficit in the records of some patients, a multivariate analysis could not be performed. Therefore, the results cannot be attributed solely to the response of headache to morphine and the role of other variables such as history of amnesia or loss of consciousness and GCS score in predicting abnormal CT scan of the study population is unclear. Hence, the findings should be interpreted with caution. Another limitation is that although we had an optimal sensitivity of $100 \%$, the protocol should be externally validated and tested on an extremely larger sample size before drawing this conclusion that those patients (under the age of 60) with a positive response of the headache to morphine can be safely excluded from referring for CT scanning if the clinical decision rules recommend otherwise. The idea opens a new horizon for future investigations.

\section{Conclusion}

This study suggests that the presence of a headache not relieved by morphine is a risk indicator which can be used as an adjunct to the existing criteria for selecting patients with minor head injury for the CT scanning. It can assist in making the decision of transferring patient in centers where CT scan is not accessible. This factor should be validated in future studies with larger sample sizes.

\section{Acknowledgment}

The authors would like to thank Dr. Soheil Saadat, MD, MPH, $\mathrm{PhD}$, Associate Professor, Sina Trauma and Surgery research center, for his consultation.

\section{Conflict of interest: None declared.}

\section{REFERENCES}

1. Rahimi-Movaghar V, Saadat S, Rasouli MR, Ghahramani M, Eghbali A. The incidence of traumatic brain injury in Tehran, Iran: a population based study. Am Surg 2011;77:112-4.

2. Cassidy JD, Carroll LJ, Peloso PM, Borg J, von Holst H, Holm L, et al. Incidence, risk factors and prevention of mild traumatic brain injury: results of the WHO Collaborating Centre Task Force on Mild Traumatic Brain Injury. J Rehabil Med 2004;(43 Suppl):28-60. CrossRef

3. Stiell IG, Wells GA, Vandemheen K, Clement C, Lesiuk H, Laupacis A, et al. The Canadian CT Head Rule for patients with minor head injury. Lancet 2001;357:1391-6. CrossRef

4. Jagoda AS, Bazarian JJ, Bruns JJ Jr, Cantrill SV, Gean AD, Howard PK, et al. Clinical policy: neuroimaging and decisionmaking in adult mild traumatic brain injury in the acute setting. Ann Emerg Med 2008;52:714-48.

5. Glauser J. Head injury: which patients need imaging? Which test is best? Cleve Clin J Med 2004;71:353-7. CrossRef

6. Haydel MJ, Preston CA, Mills TJ, Luber S, Blaudeau E, DeBlieux PM. Indications for computed tomography in patients with minor head injury. N Engl J Med 2000;343:100-5. CrossRef

7. Zare MA, Ahmadi K, Zadegan SA, Farsi D, Rahimi-Movaghar V. Effects of brain contusion on mild traumatic brain-injured patients. Int J Neurosci 2013;123:65-9. CrossRef

8. Pandor A, Goodacre S, Harnan S, Holmes M, Pickering A, Fitzgerald P, et al. Diagnostic management strategies for adults and children with minor head injury: a systematic review and an economic evaluation. Health Technol Assess 2011;15:1-202. CrossRef

9. Saadat S, Ghodsi SM, Naieni KH, Firouznia K, Hosseini M, Kadkhodaie HR, et al. Prediction of intracranial computed tomography findings in patients with minor head injury by using logistic regression. J Neurosurg 2009;111:688-94. CrossRef

10. Sharif-Alhoseini M, Khodadadi H, Chardoli M, Rahimi-Movaghar V. Indications for brain computed tomography scan after minor head injury. J Emerg Trauma Shock 2011;4:472-6.

11. Pandor A, Harnan S, Goodacre S, Pickering A, Fitzgerald P, Rees A. Diagnostic accuracy of clinical characteristics for identifying CT abnormality after minor brain injury: a systematic review and meta-analysis. J Neurotrauma 2012;29:707-18. CrossRef

12. Yavaşi O, Unlüer EE, Gün C, Sağlam C, Kayayurt K, Kiliç TY, et al. Do we routinely need cranial computed tomography for mild head injuries in Turkey? Eur J Emerg Med 2011;18:238-40. CrossRef

13. Sheehan A, Batchelor JS. A retrospective cohort study to re-evaluate clinical correlates for intracranial injury in minor head injury. Emerg Med J 2012;29:899-901. CrossRef

14. Mikhail MG, Levitt MA, Christopher TA, Sutton MC. Intracranial injury following minor head trauma. Am J Emerg Med 1992;10:24-6.

15. Saboori M, Ahmadi J, Farajzadegan Z. Indications for brain CT scan in patients with minor head injury. Clin Neurol Neurosurg 2007;109:399405. CrossRef

16. Ono K, Wada K, Takahara T, Shirotani T. Indications for computed tomography in patients with mild head injury. Neurol Med Chir (Tokyo) 
2007;47:291-8. CrossRef

17. Lee YB, Kwon SJ. A more detailed classification of mild head injury in adults and treatment guidelines. J Korean Neurosurg Soc 2009;46:451-8.

18. Mack LR, Chan SB, Silva JC, Hogan TM. The use of head computed tomography in elderly patients sustaining minor head trauma. J Emerg Med 2003;24:157-62. CrossRef

19. Miller EC, Holmes JF, Derlet RW. Utilizing clinical factors to reduce head CT scan ordering for minor head trauma patients. J Emerg Med 1997;15:453-7. CrossRef

20. Smits M, Dippel DW, Steyerberg EW, de Haan GG, Dekker HM, Vos $\mathrm{PE}$, et al. Predicting intracranial traumatic findings on computed tomography in patients with minor head injury: the CHIP prediction rule. Ann Intern Med 2007;146:397-405. CrossRef

21. Vos PE, Alekseenko Y, Battistin L, Ehler E, Gerstenbrand F, Muresanu DF, et al. Mild traumatic brain injury. Eur J Neurol 2012;19:191-8. CrossRef

22. Holmes MW, Goodacre S, Stevenson MD, Pandor A, Pickering A. The cost-effectiveness of diagnostic management strategies for adults with minor head injury. Injury 2012;43:1423-31. CrossRef

23. Stiell IG, Clement CM, Rowe BH, Schull MJ, Brison R, Cass D, et al. Comparison of the Canadian CT Head Rule and the New Orleans Criteria in patients with minor head injury. JAMA 2005;294:1511-8. CrossRef

24. Smits M, Dippel DW, de Haan GG, Dekker HM, Vos PE, Kool DR, et al. External validation of the Canadian CT Head Rule and the New Orleans Criteria for CT scanning in patients with minor head injury. JAMA 2005;294:1519-25. CrossRef

25. Papa L, Stiell IG, Clement CM, Pawlowicz A, Wolfram A, Braga C, et al. Performance of the Canadian CT Head Rule and the New Orleans Criteria for predicting any traumatic intracranial injury on computed tomography in a United States Level I trauma center. Acad Emerg Med 2012;19:2-10. CrossRef

26. Bouida W, Marghli S, Souissi S, Ksibi H, Methammem M, Haguiga H, et al. Prediction value of the Canadian CT head rule and the New Orleans criteria for positive head CT scan and acute neurosurgical procedures in minor head trauma: a multicenter external validation study. Ann Emerg Med 2013;61:521-7. CrossRef

27. Korley FK, Morton MJ, Hill PM, Mundangepfupfu T, Zhou T, Mohareb $\mathrm{AM}$, et al. Agreement between routine emergency department care and clinical decision support recommended care in patients evaluated for mild traumatic brain injury. Acad Emerg Med 2013;20:463-9. CrossRef

28. Kushner D. Mild traumatic brain injury: toward understanding manifestations and treatment. Arch Intern Med 1998;158:1617-24. CrossRef

29. De Kruijk JR, Leffers P, Menheere PP, Meerhoff S, Rutten J, Twijnstra A. Prediction of post-traumatic complaints after mild traumatic brain injury: early symptoms and biochemical markers. J Neurol Neurosurg Psychiatry 2002;73:727-32. CrossRef

30. Bazarian JJ, McClung J, Cheng YT, Flesher W, Schneider SM. Emergency department management of mild traumatic brain injury in the USA. Emerg Med J 2005;22:473-7. CrossRef

31. Farsi D, Movahedi M, Hafezimoghadam P, Abbasi S, Shahlaee A, Rahimi-Movaghar V. Acute pain management with intravenous $0.10 \mathrm{mg} / \mathrm{kg}$ vs. $0.15 \mathrm{mg} / \mathrm{kg}$ morphine sulfate in limb traumatized patients: a randomized double-blinded placebo-controlled trial. Ulus Travma Acil Cerrahi Derg 2013;19:398-404. CrossRef

32. Silka PA, Roth MM, Geiderman JM. Patterns of analgesic use in trauma patients in the ED. Am J Emerg Med 2002;20:298-302. CrossRef

33. Molina PE, Zambell KL, Zhang P, Vande Stouwe C, Carnal J. Hemodynamic and immune consequences of opiate analgesia after trauma $/$ hemorrhage. Shock 2004;21:526-34. CrossRef

34. de Nadal M, Munar F, Poca MA, Sahuquillo J, Garnacho A, Rosselló J. Cerebral hemodynamic effects of morphine and fentanyl in patients with severe head injury: absence of correlation to cerebral autoregulation. Anesthesiology 2000;92:11-9. CrossRef

\title{
KLİNIK ÇALIŞMA - ÖZET
}

\section{Minör baş travmasında beyin BT taraması çekmeden önce baş ağrısı tedavisinin rolü: İntravenöz morfin sülfat kafa içi travmasını öngörebilir mi? \\ Dr. Koorosh Ahmadi, ${ }^{1}$ Dr. Amir Masoud Hashemian, ${ }^{2}$ Dr. Elham Pishbin, ${ }^{2}$ Dr. Ali Taheriniya, ${ }^{1}$ Dr. Saba Jafarpour, ${ }^{3}$ Dr. Vafa Rahimi-Movaghar ${ }^{4}$}

\author{
${ }^{1}$ Elbruz Üniversitesi Tıp Fakültesi, Acil Tıp Anabilim Dalı, Karaj, İran \\ ${ }^{2}$ Mashad Üniversitesi Tıp Fakültesi, Acil Tıp Anabilim Dalı, Mashad, İran \\ ${ }^{3}$ Tahran Üniversitesi Tıp Fakültesi, Sina Travma ve Cerrahi Araştırma Merkezi, İran \\ ${ }^{4}$ Tahran Üniversitesi Tıp Fakültesi, Sina Travma ve Cerrahi Araştırma Merkezi, Tahran; Tahran Üniversitesi Tıp Fakültesi, \\ Şeriat Hastanesi, Nöroşirürji Kliniği, Tahran; Tahran Üniversitesi, Sinir Tedavisi için Araştırma Merkezi, Tahran, İran
}

AMAÇ: Bu çalışmanın amacı, beyin BT taramasında minör kafa travması $(\mathrm{MHI})$ bulguları olan hastalarda baş ağrısının morfine yanıtını incelemek ve BT taraması gereken hastaları tanımlamak için yeni bir risk göstergesini önermektir.

GEREÇ VE YÖNTEM: Baş ağrısı ve GCS skoru 14 veya I 5 ile gelen 15 yaş ve üstü toplam I 857 MHI hastası çalışmaya alındı. İntravenöz morfin sülfat yapıldı ve hastalar daha sonra baş ağrısının geçmesi veya süregelmesine göre değerlendirildi. Daha sonra tüm hastaların beyin BT taraması çekildi. BULGULAR: Hastalar 15-60 ve 60 yaş üstü olmak üzere iki yaş grubuna ayrıldı. Her iki grupta BT sonucu ile morfine yanıt arasında önemli bir ilişki mevcuttu $(\mathrm{p}<0.00 \mathrm{I})$. On beş ile 60 yaş arasında, baş ağrısı morfine yanıt vermiş olanların hiçbirinin BT taramasında herhangi bir anormal bulgu görülmedi (duyarlıık= \% I00). Altmış yaş üstü grupta anormal BT bulgusu ve nöroşirürji girişim endikasyonu açısından morfine yanıtın duyarılık dereceleri sırasıyla \%58.3 ve \%7l.4 idi.

TARTIŞMA: Bu çalışma morfinle geçmeyen baş ağrısının kafa içi travması için bir risk göstergesi olduğunu düşündürmektedir. BT'ye erişimin sınırlı olduğu kırsal alanlarda, BT taraması endike MHI hastalarının seçimine ilişkin mevcut kriterlere ek olarak bu protokol kullanılabilir.

Anahtar sözcükler: Ağrı yönetimi; baş ağrısı; beyin yaralanmaları; bilgisayarlı tomografi; kraniyoserebral travma; morfin.

Ulus Travma Acil Cerrahi Derg 20 I4;20(6):432-436 doi: 10.5505/tjtes.20I4.8403। 